\title{
Quality Characteristics of Chicken Burger Processed from Broiler Chicken Fed on Different Levels of Quinoa Seeds
}

\author{
Engy F. Zaki
}

\author{
Animal Breeding Department, Animal and Poultry Production Division, Desert Research Center, 1 Matariya St., B.O.P.11753 Matariya \\ Cairo, Egypt \\ Corresponding author: E-mail: angyfayz@yahoo.com
}

Received: 04 Oct 2021; Received in revised form: 11 Dec 2021; Accepted: 21 Dec 2021; Available online: 31 Dec 2021

(C)2021 The Author(s). Published by Infogain Publication. This is an open access article under the CC BY license

(https://creativecommons.org/licenses/by/4.0/).

\begin{abstract}
The study was carried out to evaluate the effect of feeding broiler chickens on different levels of quinoa seeds on the quality characteristics of chicken burger during frozen storage at $-20^{\circ} \mathrm{C}$ for 90 days. A total of 480 one-day-old chicks of (Ross 308) were used for this study. Treatments were: (T1) control group fed on corn-soybean basal diet; (T2) fed on basal diet with $5 \%$ quinoa seeds; (T3) fed on basal diet with $10 \%$ quinoa seeds; (T4) fed on basal diet with $15 \%$ quinoa seeds. Results showed that feeding broiler chickens on different levels of quinoa seeds had significant effects on $\mathrm{pH}$ values, cooking loss \%, color measurements and shear force values. No significant differences were found in shrinkage measurements. Supplemented quinoa seeds in broilers diets can be potentially used for improving color stability and controlling TBA values in processed chicken burger during frozen storage at $-20^{\circ} \mathrm{C}$ for 90days.
\end{abstract}

Keywords-Broiler feed, quinoa seeds, Chicken burger, frozen storage, Quality characteristics.

\section{INTRODUCTION}

Lipid oxidation in foods specifically, meat and meat products is the major cause of quality deterioration. Chicken meat is subjected to quality deterioration caused by lipid oxidation because of its high content of polyunsaturated fatty acids and low natural antioxidants (Aziza et al., 2010). Synthetics antioxidants have been widely used in poultry diets to prevent the lipid oxidation and improved color stability in meat and its products (Avila-Ramos et al., 2013).

Many studies have revealed that using synthetics antioxidants have been found to exhibit adverse health effects because of their toxicity and carcinogenicity. This has led to growing interest in the use of natural antioxidants in meat and meat products because of their safety and consumer acceptability (Mokhtar et al., 2014).

Quinoa (Chenopodium quinoa Willd) belongs to Chenopodiaceae. Quinoa is unique seeds it has high ability to adapt different types of soil and climatic changes therefore, it could be cultivated in different environments. Quinoa is a grain with exceptional health benefits, nutritional and functional value (Gordillo-Bastidas et al., 2016). Quinoa seeds had large variety of bioactive compounds phenolic compounds include phenolic acids (rosmarinic and chlorogenic acids), flavonoids (quercetin and isoquercetin), and nitrogen-containing compounds (betacyanins, and betaxanthins). Most of the bioactive compounds in quinoa seeds are related to their antioxidant activity (Fernández-López et al., 2020).

Using quinoa seeds extract in broiler diet significantly affected on broilers performance and improved the meat quality. Quinoa extract had antioxidative properties which resulting in delaying the lipid oxidation of broiler meat during storage (Easssawy et al., 2016).

This study aimed to evaluate the effect of feeding broiler chicken on different levels of quinoa seeds on the processing and quality characteristics of chicken burger during frozen storage at $-20^{\circ}$ for 90 days. 


\section{MATERIAL AND METHODS}

\subsection{Preparation of quinoa seeds}

Quinoa seeds (Chenopodium quinoa Willd) were supplied by the project of climatic smart agriculture entrepreneurship development of quinoa value chain in Egypt. The seeds were soaked in distilled water for $48 \mathrm{~h}$ thereafter the soaked seeds were washed with distilled water several times in a row, drained and dehulled, according to the method described by Udensi et al. (2008). Seeds were dried in a room with a temperature of 30 to $32^{\circ} \mathrm{C}$ and a humidity of $15 \%$ with stirring until complete drying (about 8 days).

\subsection{Experimental design}

The experimental procedures were approved by the Animal Breeding Department, Animal and Poultry Production Division, Desert Research Center.
A total of 480 one-day-old chicks of (Ross 308) strain were used for this study, the chicks were randomly assigned to four treatment groups. Each group consisted of 6 replicates and each replicate was made up of 20 chicks. Treatments were: (T1) control group fed on corn-soybean basal diet; (T2) fed on basal diet with $5 \%$ quinoa seeds; (T3) fed on basal diet with $10 \%$ quinoa seeds; (T4) fed on basal diet with $15 \%$ quinoa seeds. The basal diet was formulated to meet the nutrient requirements of broiler chicken following the National Research Council (NRC, 1994). Diets were offered in two feeding phase's starter: one-day-old till 21 days of age and grower: 22 days till 35 days. The composition and calculated analysis of basal diets are showed in Table 1 . The chicks were raised at $33 \pm 0.5^{\circ} \mathrm{C}$ and then the temperature was gradually decreased until $28 \pm 1{ }^{\circ} \mathrm{C}$ was reached by day 15 and then left with the case of natural temperature.

Table 1 Feed ingredients and chemical analyses of experimental diets

\begin{tabular}{lcccccccc}
\hline \multicolumn{1}{c}{ Ingredients (\%) } & \multicolumn{4}{c}{ Starter (1-21 d) } & \multicolumn{3}{c}{ Grower (22-35 d) } \\
\cline { 2 - 9 } & Q0 & Q5 & Q10 & Q15 & Q0 & Q5 & Q10 & Q15 \\
\hline Yellow corn & 53.35 & 49.60 & 45.95 & 43.44 & 57.70 & 54.05 & 50.12 & 45.56 \\
Soybean meal (44\%) & 33.14 & 32.14 & 31.00 & 29.50 & 28.65 & 28.26 & 27.34 & 26.8 \\
Corn gluten meal (62\%) & 6.35 & 6.35 & 6.35 & 6.35 & 5.75 & 5.20 & 5.20 & 5.20 \\
Quinoa & 0.00 & 5.00 & 10.00 & 15.00 & 0.00 & 5.00 & 10.00 & 15.00 \\
Soybean oil & 3.00 & 2.70 & 2.39 & 1.40 & 3.95 & 3.50 & 3.28 & 3.30 \\
Calcium carbonate & 1.23 & 1.23 & 1.23 & 1.23 & 1.07 & 1.17 & 1.15 & 1.15 \\
Di-calcium phosphate & 1.93 & 1.93 & 2.03 & 2.03 & 1.98 & 1.85 & 1.88 & 1.90 \\
Broiler premix* & 0.35 & 0.35 & 0.35 & 0.35 & 0.35 & 0.35 & 0.35 & 0.35 \\
Salt & 0.45 & 0.45 & 0.45 & 0.45 & 0.40 & 0.40 & 0.40 & 0.40 \\
DL-methionine & 0.20 & 0.20 & 0.20 & 0.20 & 0.15 & 0.17 & 0.20 & 0.22 \\
L-lysine & 0.00 & 0.05 & 0.05 & 0.05 & 0.00 & 0.05 & 0.08 & 0.12 \\
Total & 100 & 100 & 100 & 100 & 100 & 100 & 100 & 100 \\
Chemical analysis & & & & & & & & \\
ME (kcal kgG1) & 3050 & 3050 & 3050 & 3050 & 3150 & 3150 & 3150 & 3150 \\
Crude protein & 23.00 & 23.00 & 23.00 & 23.00 & 21.00 & 21.00 & 21.00 & 21.00 \\
Calcium & 1.00 & 1.00 & 1.00 & 1.00 & 0.95 & 0.95 & 0.95 & 0.95 \\
Av. phosphorus & 0.48 & 0.48 & 0.48 & 0.48 & 0.45 & 0.45 & 0.45 & 0.45 \\
\hline
\end{tabular}

*Premix: (1\%) provided the following (per Kilogram of complete diets). 1400 IU vitamin A, 3000 IU Vitamin D3, $50 \mathrm{mg}$ vitamin E, $4 \mathrm{mg}$ vitamin K, $3 \mathrm{mg}$ Vitamin B6, $6 \mathrm{mg}$ Vitamin B12, $60 \mathrm{mg}$ Niacin, $20 \mathrm{mg}$ Pantothenic acid, $0.20 \mathrm{mg}$ folic acid, $150 \mathrm{mg}$ Choline, $48 \mathrm{mg} \mathrm{Ca}, 3.18 \mathrm{mg} \mathrm{P,} 100 \mathrm{mg} \mathrm{Mn,} 50 \mathrm{mg}$ Fe, $80 \mathrm{mg} \mathrm{Zn}, 10 \mathrm{mg} \mathrm{Cu}, 0.25 \mathrm{mg}$ Co, $1.5 \mathrm{mg}$ Iodine.

\subsection{Slaughtering of birds}

At the end of the experiment (42 days), 80 birds (20 birds from each group) were selected based on similar body weight for slaughtering. Slaughtered birds were scalded in hot water bath, plucked and eviscerated manually. Chicken meat from thigh and abdominal muscles were collected, packed and frozen at $-20^{\circ} \mathrm{C}$ until further analyses and processing of chicken burger were completed. 


\subsection{Preparation of chicken burger}

Chicken meat of thigh and abdominal muscles were collected from each experimental diet and separately ground through a $3 \mathrm{~mm}$ plat meat grinder (K-R-SU, Model: KMG1700. China). Meat of each dietary treatment was formulated with $1.5 \%$ salt, $0.5 \%$ black pepper, $0.5 \%$ spices and $7.5 \%$ onion as describe by Mikhail et al. (2014). The formula of each dietary treatment was handily mixed and formed by using manual burger press machine (Metaltex No.25.17.25 Made in PRC). Chicken burgers $(1 \mathrm{~cm}$ thickness, $10 \mathrm{~cm}$ diameter and $70 \pm 2 \mathrm{~g}$ weight) were placed in plastic foam trays packed in polyethylene bags and frozen at $-20^{\circ} \mathrm{C} \pm 1$ until further analysis.

\subsection{Physical analysis}

2.5.1. pH value

Raw chicken burger was measured for $\mathrm{pH}$ value as described by Hood (1980). Ten grams of sample were homogenized with $100 \mathrm{ml}$ distilled water and measured using a digital $\mathrm{pH}$-meter Jenway 3310 conductivity and $\mathrm{pH}$ meter. Values of $\mathrm{pH}$ were determined in triplicate for each dietary treatment at $0,30,60$ and 90 days of storage at $20^{\circ} \mathrm{C}$.

\subsubsection{Cooking measurements}

Chicken burger samples of each treatment were cooked in preheated grill (at $110^{\circ} \mathrm{C}$ for $10 \mathrm{~min}$ each side) to an internal temperature $70^{\circ} \mathrm{C} \pm 1$. Three replicates per treatment were done for cooking loss measurement. Cooking loss was calculated by using the following equation as reported by Naveena et al. (2006).

Cooking loss $(\%)$

$=($ Uncooked sample weight $)-($ Cooked sample weight $) \times 100$

(Uncooked sample weight)

\subsubsection{Shrinkage measurements}

The reduction in diameter and thickness of chicken burger were measured as described by Berry (1993) using the following equation:

Reduction in diameter $(\%)=$

(Uncooked sample diameter) - (Cooked sample diameter) $\times 100$

(Uncooked sample diameter)

Reduction in thickness $(\%)=$

(Uncooked sample thickness) - (Cooked sample thickness) $\times 100$

(Uncooked sample thickness)

Shrinkage was calculated by using the following equation as reported by Murphy et al. (1975).

Shrinkage $(\%)=$

$[$ (Raw thickness - Cooked thickness $)+($ Raw diameter - Cooked diameter $)] \times 100$ (Raw thickness +Raw diameter)

\subsubsection{Shear force value}

Cooked chicken burger samples were sheared for three times at different positions by using Instron Universal Testing Machine (Model 2519-105, USA). The average shear force was calculated from the three obtained results $(\mathrm{Kg} / \mathrm{f})$.

\subsubsection{Color measurements}

Color of raw chicken burger samples was measured by Chroma meter (Konica Minolta, model CR 410, Japan) calibrated with a white plate and light trap supplied by the manufacturer (CIE, 1976). The color was expressed as lightness $\left(\mathrm{L}^{*}\right)$, the redness $\left(\mathrm{a}^{*}\right)$ and the yellowness $\left(\mathrm{b}^{*}\right)$. The average of three spectral readings at different locations was obtained for burgers of each dietary treatment during storage periods $0,30,60$ and 90 days of storage at $-20^{\circ} \mathrm{C}$.

\subsection{T.B.A value}

Measurement of lipid oxidation: The extent of lipid oxidation in raw chicken burger was assessed by measuring 2- thiobarbituric acid reactive substances (TBARS), as described by AOCS (1998). TBARS values were determined in triplicate for each sample at 0,30 , 60 and 90 days of storage at $-20^{\circ} \mathrm{C}$.

\subsection{Statistical analysis}

All data generated from each treatment were analyzed using statistical analysis system (SAS, 2000). Two- way ANOVA was applied for $\mathrm{pH}$, TBA and color measurements. In case of shrinkage measurements and physical analysis one - way ANOVA was applied.

\section{RESULTS AND DISCUSSIONS}

\section{Physical properties of chicken burger}

Physical properties ( $\mathrm{pH}$ values, cooking loss, shear force values and color parameters) of chicken burger processed from broiler fed on different levels of quinoa seeds are shown in Table 2. The results of $\mathrm{pH}$ values of chicken burger indicated that feeding broilers on different levels of quinoa seeds had significant differences in $\mathrm{pH}$ values. Burger processed from control feeding group (T1) exhibited significantly higher in $\mathrm{pH}$ value followed by burger of $\mathrm{T} 2$ group. Burger from feeding groups of high levels of quinoa seeds (T3 and T4) showed lower $\mathrm{pH}$ values. In the same line, similar trends of $\mathrm{pH}$ values were found by Marino et al. (2018). Conversely, Shim et al. (2018) found that no significant difference were found in $\mathrm{pH}$ values of broiler meat fed on different levels of dried grains. 
Table 2 Physical properties of chicken burger

\begin{tabular}{clllll}
\hline \multirow{2}{*}{ Parameters } & \multicolumn{5}{c}{ Treatments } \\
\cline { 2 - 5 } & $\mathrm{T} 1$ & $\mathrm{~T} 2$ & $\mathrm{~T} 3$ & $\mathrm{~T} 4$ & $\mathrm{SEM}$ \\
\hline $\mathrm{pH}$ & $5.64^{\mathrm{a}}$ & $5.59^{\mathrm{b}}$ & $5.46^{\mathrm{d}}$ & $5.54^{\mathrm{c}}$ & 0.01 \\
Cooking loss $(\%)$ & $42.08^{\mathrm{b}}$ & $40.83^{\mathrm{b}}$ & $49.43^{\mathrm{a}}$ & $47.64^{\mathrm{a}}$ & 1.11 \\
Shear force $(\mathrm{Kg} / \mathrm{f})$ & $2.08^{\mathrm{a}}$ & $1.59^{\mathrm{c}}$ & $1.62^{\mathrm{bc}}$ & $1.99^{\mathrm{ab}}$ & 0.11 \\
Color parameters & & & & & \\
$L$ & $49.36^{\mathrm{b}}$ & $51.47^{\mathrm{a}}$ & $50.69^{\mathrm{ab}}$ & $50.95^{\mathrm{a}}$ & 0.79 \\
$\mathrm{a}$ & $4.71^{\mathrm{ab}}$ & $4.44^{\mathrm{b}}$ & $5.09^{\mathrm{a}}$ & $4.26^{\mathrm{b}}$ & 0.15 \\
$\mathrm{~b}$ & $7.59^{\mathrm{b}}$ & $8.30^{\mathrm{ab}}$ & $8.73^{\mathrm{a}}$ & $8.99^{\mathrm{a}}$ & 0.33 \\
\hline
\end{tabular}

${ }^{\mathrm{a}-\mathrm{d}}$ means within the same row with different superscripts letters are different $(\mathrm{p}<0.05)$.

T1: control diet, T2: diet contains $5 \%$, T3: diet contains $10 \%$ and T4: diet contains $15 \%$.

SEM: standard error of means.

No significant differences were found in cooking loss between burger processed from control feeding groups (T1) and treated feeding group (T2). On the other hand, no significant differences were found in cooking loss between burger processed from (T3) and (T4) feeding groups. These results came in accordance with that obtained by Zaki et al. (2018) they found that no significant differences were observed in cooking loss of chicken burger processed from broiler fed on different types of diets and feed additives.

Results of shear force values of burger samples are revealed that feeding broilers on different levels of quinoa seeds had a significant effect on tenderness of processed chicken burgers. Burger of control group (T1) showed the higher shear force value (less tender) than the burger of quinoa seeds feeding groups. In this regard, our data reflect that the increasing of quinoa seeds level in broilers diet resulting in increasing in shear force values of processed chicken burgers. Burger of (T2) group which processed from broiler fed on the lowest level of quinoa seeds $(5 \%)$ showed the lowest shear force value (more tender) than the other quinoa feeding groups. Similar results were obtained by Marino et al. (2018) they found significant differences in WBSF values of meat fed on diets supplemented with quinoa. They found that control group showed the highest WBSF value (less tender) while; meat of quinoa feeding groups showed the lowest WBSF value (more ender).

Data of color measurements of chicken burger processed from different level of quinoa seeds showed that no significant differences were found in $\mathrm{L}^{*}$ values of chicken burger samples of T2 and T4. Slight significant differences were found between burger of T1 andT3 and T4.

Supplemented broiler diet with different quinoa levels had significant effects on redness of processed burger $\left(a^{*}\right.$ value). Burger of (T3) showed the highest *a value and no significant differences were found between T4 and T2. Chicken burger processed from broiler fed on different levels of quinoa seeds exhibited significantly higher in $b^{*}$ values than burger processed from control group (T1). View of the present data, it could be concluded that that the yellowness of chicken burger increased as feeding broiler on quinoa seeds levels increased. This finding came in accordance with the results obtained by Marino et al. (2018) they found that feeding on quinoa or/ and linseed showed a significant higher on color parameters ( $\mathrm{L}^{*}, \mathrm{a}^{*}$ and $b^{*}$ values ) than meat feeding on control groups.

Shrinkage parameters of chicken burgers processed from broiler fed on different levels of quinoa seeds are shown in Table 3. Results of reduction in diameter $\%$ revealed that supplemented broiler diets with quinoa seeds had no significant effect on reduction in diameter $\%$ of burger, despite of burger of $\mathrm{T} 2$ had the lowest reduction in diameter \% while, burger of $\mathrm{T} 3$ had the highest percentage but, the differences among burger groups were not significant. The same trends were found in data of reduction in thickness $\%$.

View of the current results, it could be concluded that shrinkage measurements $\%$ of chicken burger did not affected by supplemented broiler diets with different quinoa seeds levels. These results are in line with that obtained by Zaki et al. (2018) they found that no significant differences were found in shrinkage measurements \% of chicken burger processed from broilers fed on different feeding diets and feed additives. However, results of shrinkage measurements are consistency with data of cooking loss $\%$ and shear force values. 
Table 3 Shrinkage parameters of chicken burgers

\begin{tabular}{cccc}
\hline \multirow{2}{*}{ Treatments } & \multicolumn{3}{c}{ Parameters } \\
\cline { 2 - 4 } & Reduction in diameter & Reduction in thickness & Shrinkage \\
& $(\%)$ & $(\%)$ & $(\%)$ \\
\hline T1 & 21.23 & 19.44 & 21.69 \\
T2 & 20.12 & 18.43 & 21.53 \\
T3 & 22.37 & 22.22 & 22.73 \\
T4 & 21.90 & 21.77 & 22.51 \\
SEM & 1.49 & 2.11 & 1.44 \\
Sig. & NS & NS & NS \\
\hline
\end{tabular}

T1: control diet, T2: diet contains 5\%, T3: diet contains $10 \%$ and T4: diet contains $15 \%$.

SEM: standard error of means. Sig : significant, NS: non significant.

\section{Effect of frozen storage on the quality characteristics of chicken burger}

\section{Changes in $\mathbf{p H}$ values}

Data in Table 4 showed the pH values of chicken burger processed from broiler fed on different levels of quinoa seeds during frozen storage at $-20^{\circ} \mathrm{C}$ for 90 days. It can be noticed that a significant difference were found in $\mathrm{pH}$ values of burger treatments, the highest $\mathrm{pH}$ values found in burger of control feeding group (T1).While, slight significant differences were found among burgers of quinoa seeds feeding groups (T2, T3 and T4). Regarding frozen storage, during 30 days of storage no significant changes in $\mathrm{pH}$ values were found in both of burger of $\mathrm{T} 1$ (control feeding group) and burger of T2 (low level quinoa feeding group). Conversely, burger from higher quinoa levels feeding groups (T3 and T4) showed significantly decreased in $\mathrm{pH}$ values after 30 days of storage.

Table 4 Changes in $\mathrm{pH}$ values of chicken burger during frozen storage at $-20^{\circ} \mathrm{C}$ for 90 days

\begin{tabular}{|c|c|c|c|c|}
\hline \multirow{3}{*}{ Treatments } & \multicolumn{4}{|c|}{ Storage periods (days) } \\
\hline & 0 & 30 & 60 & 90 \\
\hline & \multicolumn{4}{|c|}{$\mathrm{pH}$ values } \\
\hline $\mathrm{T} 1$ & $5.64^{\mathrm{Ac}}$ & $5.64^{\mathrm{Ac}}$ & $5.95^{\mathrm{Ab}}$ & $6.29^{\mathrm{Aa}}$ \\
\hline $\mathrm{T} 2$ & $5.59^{\mathrm{Bc}}$ & $5.57^{\mathrm{Bc}}$ & $5.84^{\mathrm{Bb}}$ & $6.16^{\mathrm{Ba}}$ \\
\hline $\mathrm{T} 3$ & $5.46^{\mathrm{Cc}}$ & $5.35^{\mathrm{Dd}}$ & $5.78^{\mathrm{Cb}}$ & $6.01^{\mathrm{Ca}}$ \\
\hline $\mathrm{T} 4$ & $5.54^{\mathrm{BCc}}$ & $5.44^{\mathrm{Cd}}$ & $5.85^{\mathrm{Bb}}$ & $6.03^{\mathrm{Ca}}$ \\
\hline SEM & 0.02 & 0.02 & 0.02 & 0.02 \\
\hline
\end{tabular}

T1: control diet, T2: diet contains $5 \%$, T3: diet contains $10 \%$ and T4: diet contains $15 \%$. SEM: standard error of means.

However, significant increased were found in $\mathrm{pH}$ values of all burger treatments during 60 and90 days of frozen storage. These discrepancies in $\mathrm{pH}$ values during frozen storage could be explained separately, the decreasing in $\mathrm{pH}$ values could be attributed to psychrophilic bacteria especially lactic acid bacteria which resulting in breakdown of glycogen during frozen storage; thereby increase in lactic acid which caused the reduction in $\mathrm{pH}$ values (Shelef, 1975). Conversely, the increasing in $\mathrm{pH}$ values may be due to the breakdown of protein in meat during frozen storage resulting in releasing of amino acids and accumulation of ammonia and consequently, 
increasing in $\mathrm{pH}$ values (Jin et al., 2007). These results are consonance with that obtained by Alabdulkarim et al. (2012) they found that $\mathrm{pH}$ values of chicken patties significantly decreased after 20 days of frozen storage and then increased during the rest of frozen storage period (60 days). The same results were found by Ozer and Sariçoban (2010) they indicated that during frozen storage, $\mathrm{pH}$ values of chicken patties samples tended to decrease after 2 months of storage and significantly increased as the time of frozen period increased (6 months).

\section{Color parameters}

Effect of frozen storage on the color measurements of chicken burger processed from broiler fed on different levels of quinoa are shown in Table 5. It can be noticed that fresh burger (at zero time) showed slight differences in
$L^{*}$ values of all burger samples. After 30days of storage $L^{*}$ values significantly decreased, followed by significant increased throughout the storage period (90 days of storage). Fernandez-Lopez et al. (2003) indicated that $\mathrm{pH}$ values are the most factor affected on meat color because of its effect on chemical state of meat pigments. In this regard, data of $\mathrm{pH}$ values are consistency with results of $\mathrm{L}^{*}$ values which could be explained the changes in $\mathrm{L}^{*}$ values during frozen storage. Similar trend were obtained by Ozer and Sariçoban (2010) they found that L* values of chicken patties significantly decreased during 4 months of frozen storage and then increased at the end of frozen period.

Table 5 Changes in color parameters of chicken burger during frozen storage at $-20^{\circ} \mathrm{C}$ for 90 days

\begin{tabular}{|c|c|c|c|c|c|}
\hline \multirow[t]{3}{*}{ Treatments } & \multicolumn{3}{|c|}{ Storage periods (days) } & \multirow[b]{2}{*}{90} & \multirow[b]{2}{*}{ SEM } \\
\hline & 0 & 30 & 60 & & \\
\hline & \multicolumn{4}{|c|}{$L^{*}$} & \\
\hline $\mathrm{T} 1$ & $49.36^{\mathrm{Ba}}$ & $46.39^{\mathrm{Bb}}$ & $46.84^{\mathrm{Bb}}$ & $48.79^{\mathrm{Ba}}$ & 0.65 \\
\hline $\mathrm{T} 2$ & $51.47^{\mathrm{Aa}}$ & $48.22^{\mathrm{ABb}}$ & $50.22^{\mathrm{Aab}}$ & $52.49^{\mathrm{Aa}}$ & 0.65 \\
\hline $\mathrm{T} 3$ & $50.69^{\mathrm{ABab}}$ & $49.72^{\mathrm{Ab}}$ & $48.60^{\mathrm{ABb}}$ & $52.28^{\mathrm{Aa}}$ & 0.65 \\
\hline $\mathrm{T} 4$ & $50.95^{\mathrm{Aa}}$ & $46.44^{\mathrm{Bb}}$ & $47.21^{\mathrm{Bb}}$ & $48.36^{\mathrm{Bb}}$ & 0.65 \\
\hline \multicolumn{6}{|c|}{$a^{*}$} \\
\hline $\mathrm{T} 1$ & $4.71^{\mathrm{ABa}}$ & $4.41^{\mathrm{ABa}}$ & $4.46^{\mathrm{Aa}}$ & $3.55^{\mathrm{Bb}}$ & 0.19 \\
\hline $\mathrm{T} 2$ & $4.44^{\mathrm{Ba}}$ & $4.13^{\mathrm{Bab}}$ & $3.86^{\mathrm{Bb}}$ & $3.88^{\mathrm{ABb}}$ & 0.19 \\
\hline $\mathrm{T} 3$ & $5.09^{\mathrm{Aa}}$ & $4.74^{\mathrm{Aa}}$ & $4.53^{\mathrm{Aab}}$ & $4.34^{\mathrm{Ab}}$ & 0.19 \\
\hline $\mathrm{T} 4$ & $4.26^{\mathrm{Ba}}$ & $4.10^{\mathrm{Ba}}$ & $3.68^{\mathrm{Bab}}$ & $3.61^{\mathrm{Bb}}$ & 0.19 \\
\hline \multicolumn{6}{|c|}{$b^{*}$} \\
\hline $\mathrm{T} 1$ & $7.59^{\mathrm{Bb}}$ & $10.04^{\mathrm{Aa}}$ & $10.49^{\mathrm{Aa}}$ & $9.94^{\mathrm{Aa}}$ & 0.42 \\
\hline $\mathrm{T} 2$ & $8.30^{\mathrm{ABb}}$ & $10.25^{\mathrm{Aa}}$ & $9.91^{\mathrm{Aa}}$ & $8.94^{\mathrm{Aab}}$ & 0.42 \\
\hline $\mathrm{T} 3$ & $8.73^{\mathrm{Ab}}$ & $10.28^{\mathrm{Aa}}$ & $9.98^{\mathrm{Aa}}$ & $9.92^{\mathrm{Aa}}$ & 0.42 \\
\hline $\mathrm{T} 4$ & $8.99^{\mathrm{Aa}}$ & $9.79^{\mathrm{Aa}}$ & $9.88^{\mathrm{Aa}}$ & $9.10^{\mathrm{Aa}}$ & 0.42 \\
\hline
\end{tabular}

$\overline{a-b}(\rightarrow)$ means within the same row with different superscripts letters are different $(\mathrm{p}<0.05)$.

A-B $(\downarrow)$ means within the same column with different superscripts letters are different $(\mathrm{p}<0.05)$.

T1: control diet, T2: diet contains $5 \%$, T3: diet contains $10 \%$ and T4: diet contains $15 \%$.

SEM: standard error of means.

Burger of T3 showed the highest a*value (more red), followed by burger of control group (T1). No significant differences were found between burger of T2 and T4. Regarding frozen storage, decreasing trends were observed in $\left(a^{*}\right)$ values for all burger samples as the time of frozen storage increased. This may be attributed to the oxidation of oxymyoglobin to metmyoglobin which resulting in dark color (Ozer and Sariçoban, 2010). In addition, at any time of frozen storage burger of T3 showed the highest $a^{*}$ value (more red) than other burger samples. These results are in line with the results of Vieira et al. (2009) they found significant decreased were observed in $a^{*}$ of all beef 
samples as the time of frozen storage increased. The same results were found by Fernandez-Lopez (2006) who found that $\mathrm{a}^{*}$ values of burger decreased as the time of storage increased. Also, Gahruie et al. (2017) reported that significant decrease in $a^{*}$ values were found in all beef burger formulations during frozen storage.

The results revealed that a significant increased was found in $b^{*}$ values after 30days of frozen storage, after that $b^{*}$ values tended to decrease gradually with the time of storage increased up to 90days despite the fact that differences in $b^{*}$ values were not significant as the time of frozen storage increased. These results are consonance with Vieira et al. (2009) they found a significant decreased in $b^{*}$ values of meat after 90days of frozen storage. The same results were found by Ibrahim et al. (2011) they found that all chicken burger formulations tended to increased in $\mathrm{b}^{*}$ values after 45 days of storage and slightly decreased after 90 days of frozen storage.

The results of the current study revealed that supplemented quinoa seeds in broilers diets resulting in increasing the antioxidant activity in chicken meat which can be potentially used as a natural antioxidant for controlling color parameters $\left(\mathrm{L}^{*}, \mathrm{a}^{*}\right.$ and $\left.\mathrm{b}^{*}\right)$ values in processed chicken burger during frozen storage.

\section{Changes in TBA values}

Table 6 showed the TBARS values of chicken burger during frozen storage at $-20^{\circ} \mathrm{C}$ for 90 days. It can be noticed that at zero time burger of control group (T1) showed the lower TBA value and no significant differences were found between burger of $\mathrm{T} 2$ and $\mathrm{T} 3$ while, the highest TBA value were found in burger of T4. After 30 days of frozen storage significant decreased were found in all burger samples especially, in burger processed from chicken fed on high level of quinoa seeds (T4). On the other hand, the differences between burger treatments were not significant. After 60 days of storage TBA values increased for all burger treatments and such increase was continued as the time of frozen storage increased. These results are consonance with that obtained by Gahruie et al. (2017) they found that TBARS values of all burger treatments were significantly increased as the time of frozen storage increased.

Table 6 Changes in TBA values of chicken burger during frozen storage at $-20^{\circ} \mathrm{C}$ for 90 days

\begin{tabular}{|c|c|c|c|c|}
\hline \multicolumn{5}{|c|}{ Storage periods (days) } \\
\hline Treatments & 0 & 30 & 60 & 90 \\
\hline & \multicolumn{4}{|c|}{ T.B.A value (mgMDA/kg) } \\
\hline $\mathrm{T} 1$ & $0.209^{\mathrm{Ca}}$ & $0.029^{\mathrm{Bc}}$ & $0.105^{\mathrm{Bb}}$ & $0.111^{\mathrm{Bb}}$ \\
\hline $\mathrm{T} 2$ & $0.235^{\mathrm{Ba}}$ & $0.033^{\mathrm{ABd}}$ & $0.099^{\mathrm{Cc}}$ & $0.110^{\mathrm{Bb}}$ \\
\hline $\mathrm{T} 3$ & $0.239^{\mathrm{Ba}}$ & $0.034^{\mathrm{Ad}}$ & $0.109^{\mathrm{Bc}}$ & $0.116^{\mathrm{Bb}}$ \\
\hline $\mathrm{T} 4$ & $0.409^{\mathrm{Aa}}$ & $0.035^{\mathrm{Ad}}$ & $0.118^{\mathrm{Ac}}$ & $0.132^{\mathrm{Ab}}$ \\
\hline SEM & 1.88 & 1.88 & 1.88 & 1.88 \\
\hline
\end{tabular}

$\mathrm{a-d}(\rightarrow)$ means within the same row with different superscripts letters are different $(\mathrm{p}<0.05)$.

A-C $(\downarrow)$ means within the same column with different superscripts letters are different $(\mathrm{p}<0.05)$.

T1: control diet, T2: diet contains $5 \%$, T3: diet contains $10 \%$ and T4: diet contains $15 \%$.

SEM: standard error of means.

Also, Wei et al. (2017) found that TBA values of breast chicken meat were gradually increased during frozen storage period (0-5 months) but the significant increased was found during 7- 8 months of storage. Generally, it is clear that at any time of frozen storage, T.B.A. values of all burger samples remained lower than T.B.A. values at zero time. Based on the present data, it could be concluded that incorporation of quinoa seeds in broiler diets resulting in inhibited lipid oxidation of chicken burger during frozen storage. This is may be attributed to the higher antioxidant activity of quinoa seeds because of its remarkable content of phenolic and flavonoid compounds which play as a source of free radical scavenging agents. Thereby, addition of quinoa seeds in broilers diet resulted in increment of the antioxidative properties of chicken burger. This finding came in accordance with the results of Easssawy et al. (2016) they reported that addition of quinoa seeds extract in broiler diets can be successfully delayed the lipid oxidation of chicken meat during refrigerated storage for 7 days. 


\section{CONCLUSION}

The aim of the current study was to evaluate the quality characteristics of chicken burger processed from broiler chicken fed on different levels of quinoa seeds and stored under frozen storage. Addition of quinoa seeds in broiler diets has a positive effect on quality traits of chicken burger. Quinoa in broiler chicken diets would subsequently affect the oxidative stability during frozen storage and improving the color of burger during frozen storage.

\section{ACKNOWLEDGEMENT}

This work was supported by the following research project: "Climate Smart Agriculture Entrepreneurship Development of Quinoa Value in Egypt" funded by (HSBC) bank in Dubai and International Center for Biosaline Agriculture (ICBA).

\section{REFERENCES}

[1] Alabdulkarim, B., Bakeet, Z. A. N., \& Arzoo, S. (2012). Effect of frying oils on quality characteristics of frozen chicken patties incorporated with honey. African Journal of Biotechnology, 11(12), 2985-2992. https:// doi: 10.5897/AJB11.3389.

[2] AOCS. (1998). American Oil Chemists' Society. Official method Cd 19-90. 2-Thiobarbituric acid value. Direct method. In: D, Firestone (Eds.), Official Methods and Recommended Practices of the American Oil Chemists' Society, 5th ed. Champaign, p.3.

[3] Avila-Ramos, F., Pro-Martínez, A., Sosa-Montes, E., CucaGarcía, J. M., Becerril-Pérez, C., Figueroa-Velasco, J. L., Ruiz-Feria, C. A., Hernández-Cázares, A. S., \& NarcisoGaytán C. (2013). Dietary supplemented and meat-added antioxidants effect on the lipid oxidative stability of refrigerated and frozen cooked chicken meat. Poultry Science, 92 (1), 243-249. https:// doi: 10.3382 /ps. 201202409.

[4] Aziza, A. E., Quezada, N., \& Cherian, G. (2010). Antioxidative effect of dietary camelina meal in fresh, stored, or cooked broiler chicken meat. Poultry Science, 89(12), 2711-18. doi:10.3382/ps.2009-00548.

[5] Berry, B.W. (1993). Fat level and freezing temperature affect sensory, shear cooking and composition properties of ground beef patties. Journal of Food Science, 58, 34-42. https:// doi: 10.1111/j.1365-2621.1993.tb03204.x.

[6] CIE (Commission International de l'E' clairage). (1976). Official recommendations on uniform colour spaces. Colour difference equations and metric colour terms, Suppl. No. 2. CIE Publication No. 15 Colourimetry. Paris. https:// doi.org/10.1002/j.1520-6378.1977.tb00102.x.

[7] Easssawy, M. M. T., Abdel-Moneim, M. A., \& ElChaghaby, G. A. (2016). The use of quinoa seeds extract as a natural antioxidant in broilers' diets and its effect on chickens' performance and meat quality. J. Animal and
Poultry Production Mansoura Univ., 7(5), 173- 180. https:// doi: 10.21608/jappmu.2016.48696.

[8] Fernández-López, J., Viuda-Martos , M., Sayas-Barberá, M. E., Navarro-Rodríguez de Vera, C., Lucas-González, R., Roldán-Verdú, A. Botella-Martínez, C., \& Pérez-Alvarez, J. A. (2020). Chia, quinoa and their coproducts as potential antioxidants for the meat industry. Plants, 9, 1359-1380. https:// doi: 10.3390/plants9101359.

[9] Fernandez-Lopez, J. (2006). Quality characteristics of ostrich (Struthio camelus) burgers. Meat Science, 73, 295303. https://doi: 10.1016/j.meatsci.2005.12.011.

[10] Fernandez-Lopez, J., Sayas-Barbera, E., Perez-Alvarez, J. A., \& Aranda-Catala, V. (2003). Effect of sodium chloride, sodium tripolyphosphate and $\mathrm{pH}$ on color properties of pork meat. Color Research and Application, 29, 67-74. https://doi.org/10.1002/col.10215.

[11] Gahruie, H. H., Hosseini, S. M. H., Taghavifard, M. H., Eskandari, M. H., Golmakani, M. T. \&Shad, E. (2017). Lipid oxidation, color changes, and microbiological quality of frozen beef burgers incorporated with shirazi thyme, cinnamon, and rosemary extracts. Journal of Food Quality, Article ID 6350156, 9 pages. https://doi.org/10.1155/2017/6350156.

[12] Gordillo-Bastidas, E., Díaz-Rizzolo, D.A., Roura, E., Massanés, T., \& Gomis, R. (2016).Quinoa (Chenopodium quinoa Willd), from Nutritional Value to Potential Health Benefits: An Integrative Review. Journal of Nutrition \& Food Sciences, 6(3), 497-507. doi:10.4172/21559600.1000497.

[13] Hood, D. E. (1980). Factors affecting the rate of metmyoglobin accumulation in prepackaged beef. Meat Science, 4, 47-50. doi: 10.1016/0309-1740(80)90026-1.

[14] Ibrahim, M. A., Salama, M. F., \& Hussein, A. A. (2011). Production of Functional Low- Fat Chicken Burger. Australian Journal of Basic and Applied Sciences, 5(12), 3149-3154.

[15] Jin, S. K., Kim, I. S., Jung, H.J., Kim, D.H., Choi, Y.J., \& Hur, S. J. (2007). The development of sausage including meat from spent laying hen surimi. Poultry Science, 86, 2676-2684. https:// doi: 10.3382/ps.2006-00451.

[16] Marino, R. Caroprese, M., Annicchiarico , G., Ciampi, F., Ciliberti, M.G. , della Malva, A., Santillo, A., Sevi , A., \& Albenzio , M. (2018). Effect of diet supplementation with quinoa seed and/or linseed on immune response, productivity and meat quality in merinos derived lambs. Animals, 8, 204-217. https:// doi: 10.3390/ani8110204.

[17] Mikhail, W.Z.A., Sobhy, H. M., Khallaf, M. F., Ali, H. M. Z., El-Askalany, S. A., \& Ezz El-Din, M. M.,(2014) Suggested treatments for processing high nutritive value chicken burger. Annals of Agricultural Science, 59, 41-45.

[18] Mokhtar, S. M., Youssef, K. M., Morsy, N. E. (2014). The effects of natural antioxidants on colour, lipid stability and sensory evaluation of fresh beef patties stored at $4^{\circ} \mathrm{C}$. Journal of Agroalimentary Processes and Technologies, 20(3), 282-292.

[19] Murphy, E. W., Criner, P. E., \& Grey B. C. (1975). Comparison of methods for calculating retentions of nutrients in cooked foods. Journal of Agricultural Food 
Chemistry, 23, 1153-1157.___ https:// doi: 10.1021/jf60202a021.

[20] Naveena, B. M., Muthukumar, M., Sen, A. R., Babji, Y., \& Murthy, T. R. K. (2006). Quality characteristics and storage stability of chicken patties formulated with finger millet flour (Eleusine coracana). Journal of Muscle Foods, 17 (1), 92-104. https://doi.org/10.1111/j.1745-4573.2006.00039.x.

[21] NRC (1994).National Research Council. Nutrient Requirements of Poultry 9th Ed. Composition of poultry feedstuffs. National Academy Press, Washington, DC, USA.

[22] Ozer, O., \& Sariçoban, C. (2010). The Effects of Butylated Hydroxyanisole, Ascorbic Acid, and $\alpha$-Tocopherol on Some Quality Characteristics of Mechanically Deboned Chicken Patty during Freeze Storage. Czech Journal of Food Science, 28 (2), 150-160. https: // doi. org /10. 17221 /160/2009CJFS.

[23] SAS. 2000. User's Guide Statistics. SAS Institute, Inc. Cary, N.C., USA.

[24] Shelef, L. A. (1975). Microbial spoilage of fresh refrigerated beef liver. Journal of Applied Bacteriology, 39, 273-280. https://doi.org/10.1111/j.1365-2672.1975.tb00572.x.

[25] Shim, Y. H., Kim, J. S., Hosseindoust, A., Choi, Y. H., Kim, M. J., OH, S.M., Ham, H.B., Kumar, A., Kim, K.Y., Jang, A., \& Chae, B.J. (2018). Investigating meat quality of broiler chickens fed on heat processed diets containing corn distillers dried grains with solubles. Korean Journal for Food Science of Animal Resources, 38(3), 629-635. https: // doi. org /10. $5851 /$ kosfa.2018.38.3.629.

[26] Udensi EA, Arisa NU, Maduka M (2008). Effect of processing method on the level of antinutritional factors in Mucuna flagellipes. Nigerian Food Journal 26(2), 53-59. https://doi: 10.4314/nifoj.v26i2.47437.

[27] Vieira, C., Diaz, M.T., Martinez, B., \& Garcia-Cachan, M.D. (2009). Effect of frozen storage conditions (temperature and length of storage) on microbiological and sensory quality of rustic crossbred beef at different states of ageing. Meat Science, 83, 398-404. https://doi: 10.1016/j.meatsci.2009.06.013.

[28] Wei, R., Wang, P., Han, M., Chen, T., Xu, X. \& Zhou, G. (2017). Effect of freezing on electrical properties and quality of thawed chicken breast meat. Asian Australasian Journal of Animal Science, 30(4),569-575 . https:// doi.org/10.5713/ajas.16.0435.

[29] Zaki, E. F., El Faham A. I., \& Nematallah, G. M. (2018). Quality characteristics of chicken burger processed from broiler chicken fed on different types of vegetable oils and feed additives. Int. J. of Health, Animal science and Food safety 5: $1-11$. 